\title{
IMPORTANCE OF TOXIGENIC Fusarium SPECIES IN ANIMAL FOOD
}

\author{
V. Krnjaja ${ }^{1}$, J. Lević ${ }^{2}$, S. Stanković ${ }^{2}$ \\ ${ }^{1}$ Institute for Animal Husbandry, Autoput 16, P. Box 23, 11080 Belgrade-Zemun, Republic of Serbia \\ ${ }^{2}$ Maize Research Institute „Zemun Polje”, Slobodana Bajića 1, 11185 Belgrade-Zemun, Republic of \\ Serbia \\ Corresponding author: vesnakrnjaja.izs@gmail.com \\ Invited paper
}

\begin{abstract}
Numerous plant species, which are main components of various mixtures used in animal nutrition, can be contaminated by mycotoxins created by large number of pathogenic and toxigenic fungi (moulds). From the aspect of animal nutrition, most important are cereals and oil crops (in form of meals) because they constitute the highest share in preparation of animal food, and on the other hand, they are especially sensitive to toxigenic fungi and can contain mycotoxins above maximum allowed quantity. Contamination of plants or certain plant parts, of which the grain is of major importance, occurs in the field or during storage, as consequence of growth of toxigenic fungi. Numerous factors favour and contribute to growth of moulds, such as environment conditions, stress, sensitivity of genotype to fungi and insects, moisture content, etc. Species of the Fusarium, Aspergillus and Penicillium genera, from the mycotoxicological aspect, are the most important pathogens isolated in livestock feed in Serbia. However, the most studied plant pathogenic fungi are Fusarium species, and there are several reasons for this. Firstly, each year, in higher or lower percentage, they cause diseases on maize, wheat, barley and other cereal species, which are major component of animal and human nutriiton. Secondly, they have cause in certain years mass incidence of mycotoxicosis in animals, esepcially in pigs. F. graminearum is the most important pathogenic species for wheat, barley and maize, $F$. poae for wheat and barley, whereas species from the section Liseola ( $F$. verticillioides, $F$. subglutinans and $F$. proliferatum) are more significant for maize and sorghum. In addition to above mentioned, the presence of other Fusarium species was determined, although in small percentage, but very toxigenic and cannot be neglected as potential animal food contaminants. Considering the prevelance of certain toxigenic species in Serbia, three groups of mycotixins produced by Fusarium fungi species can be considered as the most important from the aspect of animal health. Within the group of trichothecenes, deoxynivalenol (DON) is associated with situations when pigs refuse to eat, whereas toxin T-2 can cause reproduction disorders in sows. Other group includes zearalenone $(\mathrm{ZON})$ and its
\end{abstract}


derivatives which cause estrogenism. Third group includes fumonisins which are associated with specific syndroms of toxicity such as equine leukoencephalomalacia (ELEM) and porcine pulmonary oedema (PPE). Growth and presence of Fusarium species in grains and animal food, becuase of the production of mycotoxins, has been current topic in many researches world wide.

Key words: toxigenic Fusarium species, mycotoxins, animal food

\section{Introduction}

Cereals and cereal mixtures are widely used as source of energy for farm animals. Unfortunately, numerous fungi species can develop on cereals in the field and during storage (warehouse) and contaminate the animal food by mycotoxins which exhibit toxic effects on animals and humans (Biagi, 2009). Climatic conditions and growing of cereals on large areas in Republic of Serbia are conducive to the growth of toxigenic species, such as Fusarium spp., Aspergillus spp. and Penicillium spp., resulting in frequent contamination of animal food by their secondary metabolites. In Republic of Serbia, the most often isolated species in animal food are fungi of Fusarium species, as well as their mycotoxins (Krnjaja et al., 2009b).

Species of the Fusarium are characterized by excellent interspecies and intraspecies variability in regard to morphological, physiological, genetic and ecological properties. Due to high variability of these properties, species of the Fusarium genus are wide spread, and mainly cosmopolitan, although certain number of species is dominant in the regions with tropical and sub-tropical or moderate climate (Burgess et al., 1994; Leslie and Summerell, 2006).

Fusarium species are wide spread in the soil and organic substrates, and they are isolated everywhere (Booth, 1971). They are the most often isolated plant pathogens among imperfect fungi Deuteromycetes. Genus Fusarium is divivded into several sections on the basis of anamorph characteristics. Telemorph of $F$. avenaceum (section Artrosporiella/Roseum), F. graminearum (section Discolor/Fusarium) and F. equiseti (section Gibossum) belong to genus Gibberella (Booth, 1971; Gerlach and Nirenberg, 1982). Sex stadiums have not been detected in F. culmorum (section Discolor/Fusarium), F. oxysporum and F. redolens (section Elegans) (Booth, 1971). During the evolution of species of Fusarium genus, the process of their adjustment (specialization) to certain plant species took place - hosts in different habitats (specialized forms, varieties) or even genotypes of the same plant species (breed). Certain species, especially those which cause conductive vessel wilt ( $F$. oxysporum), are more specialized towards the plant host than other species which cause rot of roots and vegetative plant parts (Burgess et al., 1994). 
Many attempts have been made to create a uniform procedure for identification of species of Fusarium genus, but to date this has not yet been realized. Every approach developed so far based on morphological characteristics had positive aspects but also disadvantages. Therefore, resulting from various systems of taxonomy and nomencalture, there is a great confusion in regard to indentification of the species of Fusarium genus. Actual consideration of the number and taxonomy of species Fusarium genus will be possible after detailed phylogenetic studies at the molecular level. Recent studies of the basic organization of the genome of species of Fusarium genus and of their morphological and metabolic properties, presented at the $6^{\text {th }}$ European Fusarium Seminar (Berlin), indicate that the phylogenetic tree of the Fusarium genus will be different from the tree presented for this genus by Booth (1971) (Tančić, 2009). Taking into consideration the morphological, physiological, genetic/phylogenetic diversity of species of Fusarium genus, over 80 species have been determined within this genus so far (Moretti, 2002).

Fusarium species form long, multicellular, spindle-shaped macroconidia. These macroconidia define the morphological characteristics of the genus. Many species will also form small, usually single-cell microconidia which vary in their shape from fusiform to oval to spherical. Also, some species form resistant chlamidospores which are important for longer survival. Microconidia and macroconidia are important for spreading of fungi by wind and splash. Conidia are, aslo, usually propagules which participate in the infection of host plant (Glenn, 2007).

Fusarium species can cause vascular wilting, decay of seedlings, root rot, crown rot resulting in drying of leaves. Premature decay of forage plants in our country is significantly contributed to by some factors of the environment. Long dry periods during summer lead to weakining of the plant vitality and increase their sensitivity to species of the Fusarium genus. Strong winter frost, in periods without snow cover, damage the crown rot of plants making them more sensitive to weakness parasites (Todorov et al., 1995). Many questions are focued on the ability of Fusarium species to penetrate the root directly, their compatibility to host and interaction with other plant stress factors. Some isolates of Fusarium species, joined within the complex of root rot of forage plants, penetrate the root directly. Injuries of the root lead to increased occupation by other isolated (Leath and Kendall, 1978).

Because of exceptional diversity of species of Fusarium genus in regard to morphological, physiological, genetic and pathogenic properties, as well as mycotoxin spectrum which they produce, study of the presence and distribution of Fusarium species and their mycotoxins is very important, as well as risk assessment of the potential damage caused by these pathogen fungi and potentially toxigenic fungi species. In this paper the most important Fusarium species which are potentially toxigenic species in cereals as basis of animal food, are reviewed. 


\section{F. graminearum Schwabe}

F. graminearum (teleomorph Gibberella zeae (Schw.) Petch.) is cosmopolitan, and most often it is present in areas with moderate and tropical climate, where it causes maize root rot, rot of stem and of the maize cob, as well as fusariosis of the wheat ear and other species of the family Poaceae. F. graminearum is very toxigenic species which synthesizes deoxynivalenol and zearalenone, mainly on maize and wheat (Lević, 2008). In addition to primary hosts - wheat, maize and barley, it parasites also on other annual and perennial plants (Leslie and Summerell, 2006).

For many years $F$. graminearum was divided into two taxons known as $F$. graminearum Group 1 and $F$. graminearum Group 2. Morphologically it is very difficult to distinguish these two groups, but there are important ecological and pathological differences (Leslie and Summerell, 2006). Members of Group 1 rarely form perithecia in nature and are heterothallic. Contrary to this, members of Group 2 form abundantly perithecia in nature and are homotallic. Perithecia in both groups are similar and have teleomorph stage Giberella zeae (Schw.) Petch. (Burgess et al., 1994). In recent years, by applying phylogenetic analyses based on comparisons of DNA sequences of various genetic loci several new species were established. In morphological and molecular analyses of isolates in Groups 1 and 2 it was established that isolates in Group 1 belonged to species $F$. pseudograminearum. Gibberella coronicola is name given to heterothallic teleomorph of $F$. pseudograminearum. Populations in Group 2 kept the original name $F$. graminearum and have teleomorph Gibberella zeae (Aoki and O'Donnell, 1999). O'Donnell et al. (2004), based on extensive molecular phylogenetic analyses of 11 nuclear genes assumed additional revisions in taxonomy of homothallic population of G. zeae/F. graminearum. Nine phylogenetically different bio-geographical structural lines were identified, which have been formally considered as different species, including $F$. graminearum sensu stricto and $F$. pseudograminearum (O'Donnell et al., 2004).

Isolates of $F$. graminearum produce trichothecenes deoxynivalenol (DON) (and its derivatives), as well as polyketide estrogenic metabolite zearalenone (ZON) (Glenn, 2007). Based on production of different trichothecenes, $F$. graminearum can be divided into two chemotaxonomic groups - DON chemotype and nivalenol (NIV) chemotype. DON is the most present mycotoxin in cereals and DON chemotypes of Fusarium were detected worldwide. On the other hand, NIV chemotype has been detected more in limited regions, such as certain Asian (Hsia et al., 2004) and European countries (Logrieco et al., 2002), and lately, it was also detected in North America (Gale et al., 2011). In some countries, there are legally 
regulated limits of DON concentration in cereals. So, more attention is focused on DON compared to NIV, of trichothecene mycotoxins (Nakajima, 2007).

In agro-ecological conditions of Serbia, species $F$. graminearum has very often been identified on wheat and maize. According to results obtained by Bočarov-Stančić (1996, 1998) and Bočarov-Stančić et al. (2000), of Fusarium species determined in analyzed wheat garain, species $F$. graminearum was the most frequent. Stojanovic et al. (2005) established $5.03 \%$ F. graminearum in investigated samples of wheat grain with content of ZON of up to $500 \mu \mathrm{g} \mathrm{kg}^{-1}$. According to these authors, ZON concentration in samples of wheat flour ranged from 66.67 to $200 \mu \mathrm{g} \mathrm{kg}^{-1}$.

In Serbia, ZON is one of the most important fusariotoxins causing mycotoxicosis in animals and one of the most common contaminants of livestock mixtures used in nutrition and of their components (Bočarov-Stančić et al., 1995; Lević et al., 2004). In the analysis of the content of DON in maize samples which were artificially infected with $F$. gramineraum, Abramovic et al. (2005) established DON concentrations which did not exceed maximum allowed values, regardless of the artificial inoculation with $F$. graminearum. These results were explained by authors as the consequence of absence of moisture and exceptionally high temperatures in the period of artificial inoculation of plants (Abramovic et al., 2005).

In the study of the incidence of toxigenic Fusarium species in wheat during 2005 and 2006, Stanković et al. (2007) identified 13 Fusarium species, of which F. graminearum was the most common with 35.2\% (2005) and 12.5\% (2006). In sampled maize kernels, post-harvest, among isolated Fusarium species the most common was species $F$. graminearum (17.8\%) (Krnjaja et al., 2006). Of six identified Fusarium species on maize kernels in warehouse, species $F$. graminearum was the third in regard to its incidence, and according to the mycotoxicological aspect it is very important in the period June-September when it was mainly identified in samples (5-11\%) (Krnjaja et al., 2007). Krnjaja et al. (2008), in post-harvest wheat samples, identified eight species from Fusarium genus, of which $F$. graminearum was the most common with $63.5 \%$. In the analysis of the presence of $F$. graminearum on different parts of the wheat ear, Levic et al. (2008a) established that this species was most common on the grain (55.5\%) and whole rachis (34.7\%). Krnjaja et al. (2009a) established also high incidence of $F$. graminearum $(7.8-10.8 \%)$ in all studied treatments where wheat was fertilized with different types of fertilizer and in different times - first treatment was slurry before sowing and in plant feeding, the second treatment was manure before sowing and urea in plant feeding, and the third treatment urea in the plant feeding, compared to the control treatment without application of fertilizer $(3.5 \%)$.

In the analysis of the content of DON mycotoxins in wheat ear, Balaž et al. (2007) established $353.4 \mu \mathrm{g} \mathrm{g}^{-1}$ of this toxin in grain samples with exhibited 
symptoms of fusariosis ( $F$. graminearum) on the ear, $0.225 \mu \mathrm{g} \mathrm{g}^{-1}$ in grain samples above the infected part of the ear, and $0.125 \mu \mathrm{g} \mathrm{g}^{-1}$ in grain samples below the infected part of the ear. Presence of ZON in concentration of $2.1 \mu \mathrm{g} \mathrm{g}^{-1}$ was determined in grain samples from the wheat ear with symptoms of fusariosis (Balaž et al., 2007).

In wheat samples collected from different locations in Serbia prior to harvest in 2005 and 2006, in which the $F$. graminearum had been identified as the most common species, the concentrations of ZON of 37 to $331 \mu \mathrm{g} \mathrm{kg}^{-1}$ and of DAS and T-2 toxin from 31 to $125 \mu \mathrm{g} \mathrm{kg}^{-1}$ were determined (Stanković et al., 2007). In the analysis of samples of wheat collected during 2004 and 2005 in Vojvodina, it was established that $41.6 \%$ of samples were contaminated by DON with concentrations ranging from 57 to $1840 \mu \mathrm{g} \mathrm{kg}^{-1}$ (Jurić et al., 2007). In the analysis of 14 isolates of $F$. graminearum isolated in wheat, as producers of DON, concentrations in the range from 160 to $45.260 \mu \mathrm{g} \mathrm{kg}^{-1}$ were established (Stanković et al., 2008a).

\section{F. sporotrichioides Sherbakoff and $F$. poae (Peck) Wollenweber}

F. sporotrichioides was determined in regions with cold and moderate climate, most often in plant species of the family Poaceae. It is especially significant as pathogen of wheat and maize. One of the first species of Fusarium genus which was determined as toxigenic and that mycotoxins produced by it can cause alimentary toxic aleukia in humans and animals. It synthesizes T-2 toxin, diacetoxyscirpenol, butenolide, fusarin $\mathrm{C}$, moniliformin, zearalenone, etc. (Lević, 2008). F. sporotrichioides can develop even in very low temperatures sand can be isolated from seeds which survived the winter under snow. It can also be isolated from different substrates such as grasses, small grains and alfalfa, but in general it is weak pathogen (Leslie and Summerell, 2006).

$F$. poae is cosmopolitan, determined in regions with moderate and tropical climate, it parasites on numerous hosts: seedlings of herbaceous plants, species of the family Poaceae, sugar cane, rice, citrus fruits, carnation and other plant species. It synthesizes fusarenone- $\mathrm{X}$, nivalenol, diacetoxyscirpenol, $\mathrm{T}-2$ toxin, beauvericin, fusarin C, etc. (Lević, 2008).

Stojanović et al. (2005) established significant presence of $F$. poae $(8.80 \%)$ in studied grains of three wheat cultivars in grain fractions with dark germ category. In the analysis of 57 samples of poultry feed in the period from 1998 to 2002, Zivković et al. (2005) established significant presence of T-2 toxin in concentrations from $<300 \mu \mathrm{g} \mathrm{kg}^{-1}$ (19 samples of food), $500 \mu \mathrm{g} \mathrm{kg}^{-1}$ (18 samples of food) and $1,000 \mu \mathrm{g} \mathrm{kg}^{-1}$ (3 samples of food). In six samples of food, in addition to T-2 toxin, also DAS was present. Clinical picture and damages varied depending 
on the concentration of mycotoxins and age of chickens (Živković et. al., 2005). In the post-harvest wheat grain, Krnjaja et al. (2008) established high presence of $F$. sporotrichioides $(20.9 \%)$ and low presence of $F$. poae $(0.9 \%)$. Potential of Serbian isolates of $F$. poae for bio-synthesis of trichothecenes from the group A was low, because concentration of DAS did not exceed $80 \mu \mathrm{g} \mathrm{L}^{-1}$, i.e. concentration of T-2 toxin did not exceed $240 \mu \mathrm{g} \mathrm{L}^{-1}$ (Bočarov et al., 2007). In the study of the effect of various types of fertilizer on infection of wheat grain with Fusarium species, that low presence of $F$. sporotrichioides was established in all studied treatments with fertilizer (0.3-0.6\%) and of $F$. poae in treatments where manure was used before sowing and urea in plant nutrition (0.3\%) (Krnjaja et al., 2009a).

\section{F. verticillioides (Saccardo) Nirenberg, F. proliferatum (Matsushima) Nirenberg and F. subglutinans (Wollenweber \& Reinking) Nelson, Toussoun \& Marasas}

Species $F$. verticillioides (syn $F$. moniliforme Sheldon), $F$. proliferatum and F. subglutinans belong to the section Liseola (Nelson et al., 1983). F. verticillioides (teleomorph Gibberella moniliformis Wineland, mating population A) is cosmopolitan, maize and sorghum pathogen, causes seedlings and root rot in rice, sugar cane, cotton, small grains, banana, pineapple and tomato fruit, and many other plants. It synthesized fumonisins, fusaric acid, fusarin $\mathrm{C}$ and trichothecenes (Lević, 2008). Fumonisins are the most important mycotoxins produced by $F$. verticillioides. Fumonisin $\mathrm{B}_{1}\left(\mathrm{FB}_{1}\right)$ is the best known and studied of all fumonisins. They can be isolated in different types of food, but maize and maize products are with the highest risk of contamination (Leslie and Summerell, 2006). There were some significantly dissenting opinions in regard to the name of this Fusarium species, some taxonomists called it $F$. moniliforme and some used the name $F$. verticillioides. The name $F$. verticillioides is now used more (Leslie and Summerell, 2006). Many taxonomic concerns were associated with identification of the species $F$. verticillioides, and eventually several species were separated, including species $F$. proliferatum and $F$. subglutinans which are commonly joined with maize (Nelson et al., 1983; Marasas, 1984). In regard to morphological criteria, precision in identification of species was based on application of the biological species concept in relation to different mating populations (Leslie, 1991, 1995), same as later application of the biological species concept based on analysis of DNA sequences (Nirenberg and O'Donnell, 1998). Detection of mating populations and application of the biological species concept were possible because perithecia formed in heterothallic form in the culture when isolate strains belonging to different mating types were grown together (Leslie, 1991, 1995). It was recorded that $F$. moniliforme sensu Snyder \& Hansen included isolates of some other species and not $F$. verticillioides. The name $F$. verticillioides should only be used for 
isolates which have teleomorph Gibberella moniliformis (G. fujikuroi mating population A) and not as replacement for F. moniliforme sensu (Leslie and Summerell, 2006).

$F$. proliferatum is cosmopolitan, determined as pathogen of many different plant species, including maize, orchids, asparagus, etc. It synthesizes beauvericin, fusaproliferin, fusaric acid, fusarins, moniliformin, etc. (Lević, 2008). In high concentrations it produces fumonisins (Leslie and Summerell, 2006). F. proliferatum was first described as Cephalosporium species and then as Fusarium species. Telemorph of this species is G. intermedia (Kuhlman) Samuels, Nirenberg \& Seifert (G. fujikuroi mating population D) (Leslie and Summerell, 2006).

$F$. subglutinans is cosmopolitan, it prevails in regions with moderate climate where it causes maize disease, as well as disease in other species of the family Poaceae. It synthesizes moniliformin, beauvericin, fusaric acid, fusaproliferin etc. (Lević, 2008). It produces in small concentrations, or not at all, fumonisins. The telemorph of this species is Gibberella subglutinans Nelson, Toussoun \& Marasas (G. fujikuroi mating population E) (Leslie and Summerell, 2006).

Stojanović et al. (2005) established significant presence of $F$. subglutinans $(17.61 \%)$ in investigated grains of three wheat cultivars in fractions healthy, dark germ and slightly fusarious contaminated grains. In the study of the presence of Fusarium spp. and fumonisin in grain of three wheat cultivars (PKB Lepoklasa, Jugoslavija and Francuska) Protić and Protic (2005) established the presence of infection with Fusarium spp. In all studied wheat cultivars. The most common was species $F$. graminearum, whereas $F$. moniliforme and $F$. proliferatum were determined in lower percentage. Average concentration of fumonisins in wheat grain samples was $0.62 \mathrm{mg} \mathrm{kg}^{-1}$ (Protić and Protić, 2005). In the study of the toxigenic potential for bio-synthesis of ZON and trichothecenes from group A (T-2 and DAS) in the most common species $F$. verticillioides isolated in the maize kernel harvested in 2005, Jajić et al. (2007) established that the studied isolates of $F$. verticillioides did not bio-synthesize $\mathrm{ZON}$, and of trichothecenes of group A, T2 toxin was synthesized in concentration of $80-240 \mu \mathrm{g} \mathrm{L}^{-1}$, and DAS toxin was not synthesized. In post-harvest wheat grain, Krnjaja et al. (2008) established relatively high presence of $F$. proliferatum $(5.2 \%), F$. subglutinans $(3.5 \%)$ and $F$. verticillioides $(1.7 \%)$. In the study of the toxicological profile and fertility of 24 isolates of $F$. proliferatum isolated from maize plants on different locations in Serbia, Stanković et al. (2008b) established that all studied isolates produced relatively high level of fumonisin $\mathrm{B}_{1}\left(\mathrm{FB}_{1}\right)$ (to $\left.3950 \mu \mathrm{g} \mathrm{g}-1\right)$. Seven studied isolates belonged to MATD-1 and 17 isolates belonged to MATD-2 mating type (Stanković et al., 2008b). In the study of the effect of different fertilizer types on infection of wheat grain with Fusarium species, low presence of $F$. subglutinans $(0.2 \%)$ was established in treatment with fertilizer compared to control treatment without fertilizer (Krnjaja et al., 2009a). 


\section{Strategies of control of toxigenic fungi}

Strategy which includes application of good agricultural practice and good storage practice with reduced effect of mycotoxins, with implementation of all regulations and other measures, can provide production of safe food for humans and animals (Lević et al., 2008b).

In general, good practice that reduces the grain contamination by toxigenic fungi species in the field and in warehouses (Fusarium spp., Penicillium spp. and Aspergillus spp.) is at the same time good practice to reduce contamination of grain with mycotoxins (Stack, 2000). The risk of mycotoxins does not exist if in the animal and human nutrition maize is used from fields free of cob fusariosis, which is subsequently dried and stored in standard way. Incidence of fusariosis of cob in the fields or in storage opens the issue to which extent such maize can be used in animal and human nutrition, without causing the mycotoxicosis. Similar is situation with fusariosis of ear and kernel of small grains.

When fungicides are used in control of cereal fusariosis, this reduces the risk of contamination. However, resistance of Fusarium species to certain fungicides has been registered. Selection of cereal cultivars resistant to Fusarium species is also one option to reduce the mycotoxins in cereals (Placinta et al., 1999).

If the infection by toxigenic fungi species and mycotoxin contamination occur, chemical treatments which include calcium hydroxide monomethylamine, sodium bisulphite or ammonia are recommended as measures to reduce the level of fusariotoxins (Placinta et al., 1999). Dilution of contaminated cereals with other components of livestock food is another option which enables establishing of control before cereals are incorporated in livestock feeds.

Based on all presented in the paper, it is apparent that prevention strategies are probably more efficient compared to remedial action in reduction of risk to animal health. Many countries are attempting to define in the legislation and regulations maximum allowed quantities of certain mycotoxins in plant products intended for nutrition of certain categories of domestic animals. According to Regulation on maximum quantities of harmful substances and ingredients in animal feed (Službeni list SFRJ, 1990) in Serbia, maximum allowed quantities of aflatoxin, ochratoxin, zearalenonae and total trichothecenes (T-2 toxin and DAS) are determined, as well as criteria for determination of the hygiene quality of mixture and of raw material used for production of animal feeds. These regulations have to be harmonized with EU recommendations, and supplemented with new mycotoxins (DON, $\mathrm{FB}_{1}$ ). 


\title{
Conclusion
}

Animal food may be contaminated with Fusarium species and fusariotoxins. A number of compounds within fusariotoxins have been implicated in spontaneous worldwide cases of mycotoxicoses in livestock. Knowledge of the taxonomic identity and mycotoxigenic potential of the various Fusarium species are important for development of strategies for monitoring and managing mycotoxin contamination of grain. Analysis of animal food gives the farmers information about the optimum utilization of nutrients in animal food; to producers, information about components which are included in feed mixtures and that they are suitable for different processes in livestock production; to scientists and researchers to be able to evaluate animal performance based on characteristics of animal food; to selection plant breeders it provides information on nutritional value of new cultivars/hybrids; and the most important information on undesirable contaminants in animal food which directly influence the safety of food of animal origin. Annual results and results obtained in studies lasting several years of presence and frequency of incidence of Fusarium species and their mycotoxins in animal food are very important because of application of preventive measures, as well as raising of the public awareness of consequences of the adverse effect of these contaminants in the food chain. However, in future studies, it remains to be determined how temperature, moisture and host genotype influence the geographical distribution of Fusarium species, their interaction and development of cereal diseases and production of mycotoxins.

\section{Acknowledgment}

Research was financed by the Ministry of Education and Science, Republic of Serbia, project TR-31023.

\section{Značaj toksigenih Fusarium vrsta u hrani za životinje}

\author{
V. Krnjaja, J. Lević, S. Stanković
}

\section{Rezime}

Brojne biljne vrste, koje čine sastavni deo različitih smeša hrane za životinje, mogu biti kontaminirane mikotoksinima koje stvara veliki broj patogenih i toksigenih gljiva (plesni). Sa stanovišta ishrane životinja najznačajnija su žita i uljane kulture ( $u$ vidu brašna) jer čine najveći udeo prilikom pripreme hrane, a s druge strane, posebno su osetljive prema toksigenim gljivama i mogu da sadrže 
mikotoksine iznad maksimalne dozvoljene količine. Do kontaminacije biljaka ili pojedinih njenih delova, od kojih je zrno najznačajnije, dolazi u polju ili tokom skladištenja kao posledica razvoja toksigenih gljiva. Brojni su činioci koji pogoduju razvoju plesni, kao što su uslovi spoljašnje sredine, stres, osetljivost genotipa prema gljivama i insektima, sadržaj vlage i drugo.

U Srbiji vrste iz rodova Fusarium, Aspergillus i Penicillium su sa mikotoksikološkog aspekta najznačajniji patogeni izolovani iz hrane za životinje. Međutim, među najproučavanijim biljnim patogenim gljivama su Fusarium vrste, i to iz više razloga. Prvo, one svake godine u većem ili manjem procentu prouzrokuju bolesti na kukuruzu, pšenici, ječmu i drugim vrstama žita, koje su glavne komponente hrane za ljude i životinje. Drugo, one su u nekim godinama prouzrokovale masovnu pojavu mikotoksikoza životinja, posebno svinja. $F$. graminearum je najznačajnija patogena vrsta za pšenicu, ječam i kukuruz, $F$. poae za pšenicu i ječam, dok su vrste iz sekcije Liseola ( $F$. verticillioides, $F$. subglutinans i $F$. proliferatum) značajnije za kukuruz i sirak. Osim ovih, utvrđeno je prisustvo i drugih Fusarium vrsta, koje su, iako prisutne u malom procentu, veoma toksigene i ne mogu se zanemariti kao potencijalni kontaminatni hrane za životinje.

S obzirom na rasprostranjenost pojedinih toksigenih vrsta gljiva u Srbiji, od posebne važnosti za zdravlje životinja mogu se razmatrati tri grupe mikotoksina koje proizvode Fusarium vrste gljiva. Unutar grupe trihotecena, deoksinivalenol (DON) je povezan sa odbijanjem hrane kod svinja, dok T-2 toksin može prouzrokovati poremećaje u reprodukciji kod krmača. Druga grupa obuhvata zearalenon (ZON) i njegove derivate koji prouzrokuju estrogenizam. Treća grupa uključuje fumonizine koji su povezani sa specifičnim sindromima toksičnosti kao što su leukoencefalomalacija i edem pluća. Razvoj i prisustvo Fusarium vrsta u žitima i hrani za životinje zbog produkcije mikotoksina, poslednjih godina je veoma aktuelna tema u brojnim istraživanjima širom sveta.

\section{References}

ABRAMOVIĆ B.F., JAJIĆ I.M., JURIĆ V.B. (2005): Determination of deoxynivalenol in corn. Proc. Nat. Sci., 108, 139-146.

AOKI T., O'DONNELL K. (1999): Morphological and molecular characterization of Fusarium pseudograminearum sp. nov. formerly recognized as the Group 1 population of $F$. graminearum. Mycologia, 91, 597-609.

BALAŽ F.F., JAJIĆ I.M., BAGI F.F., STOJŠIN V.B., ABRAMOVIĆ B.F. (2007): The content of deoxynivalenol and zearalenone in certain parts of Fusarium infected wheat heads. Proc. Nat. Sci., 113, 9-16.

BIAGI G. (2009): Dietary supplements for the reduction of mycotoxin intestinal absorption in pigs. Biotechnology in Animal Husbandry, 25, 5-6, 539-546. 
BOČAROV-STANČIĆ A. (1996): Učestalost Fusarium spp. i njihovih mikotoksina u pšeničnom zrnu. U monografiji: Proizvodnja i prerada žita i brašna. Tehnološki fakultet, Zavod za tehnologiju žita i brašna, Novi Sad, 131-142. BOČAROV-STANČIĆ A. (1998): Učestalost gljiva iz rodova Aspergillus, Fusarium i Penicillium i njihovih mikotoksina u žitaricama iz Jugoslavije. Četvrti jugoslovenski kongres o zaštiti bilja i međunarodni simpozijum o integralnoj zaštiti ratarskih biljaka, Vrnjačka Banja, 21.-26. septembar, 1998. godine. Zbornik rezimea, 46.

BOČAROV-STANČIĆ A., PROTIĆ N., ŽIVKOVIĆ B. (1995): Pregled mikrobioloških i mikotoksikoloških istraživanja stočne hrane tokom 1992. i 1993. godine u Vojvodini. Biotehnologija u stočarstvu, 1-2, 63-68.

BOČAROV-STANČIĆ A., ŠKRINJAR M., MAŠIĆ Z. (2000): Prirodno prisustvo Fusarium vrsta i fuzariotoksina kod žitarica i krmnih smeša poreklom iz Jugoslavije. 12. Savetovanje veterinara Srbije, Vrnjačka Banja, 12.-15. 9. 2000. godine. Zbornik referata i kratkih sadržaja, 78-84.

BOČAROV-STANČIĆ A.S., LEVIĆ J.T., STANKOVIĆ S.Ž., KRNJAJA V.S., KOVAČEVIĆ T.M., TANČIĆ S.L. (2007): The toxigenic potential of Fusarium poae originated from wheat. Proc. Nat. Sci., 113, 113-123.

BOOTH C. (1971): The genus Fusarium. Commonwealth Mycological Institute, Kew, Surrey, England.

BURGESS W.L., SUMMERELL A.B., BULLOCK S., GOTT P.K., BACKHOUSE D. (1994): Laboratory manual for Fusarium research. Third edition, Fusarium Research Laboratory Department of Crop Sciences University of Sydney and Royal Botanic Gardens, Sydney, 133 p.

CHI C.C., CHILDERS W.R., HANSON E.W. (1964): Penetration and subsequent development of three Fusarium species in alfalfa and red clover. Phytopathology, 54, 434-437.

D’MELLO J.P.F (2004): Contaminants and toxins in animal feeds. In: FAO (ed), Assessing quantity and safety of animal feeds, 107-128.

GALE L.R., HARRISON S.A, WARD T.J., O'DONNELL K., MILUS E.A., GALE S.W., KISTLER H.C. (2011): Nivalenol-type populations of Fusarium graminearum and $F$. asiaticum are prevalent on wheat in southern Louisiana. Phytopathology, 101,124-134.

GERLACH W., NIRENBERG H. (1982): The genus Fusarium - a pictorial atlas. Mitteilungen aus der Biologischen Bundesanstalt für Land - und Forstwirtschaft. Berlin - Dahlem, 209 p.

GLEN A.E. (2007): Mycotoxigenic Fusarium species in animal feed. Animal Feed Science and Technology, 137, 213-240.

HSIA C.C., WU Z.Y., LI Y.S., ZHANG F., SUN Z.T. (2004): Nivalenol, a main Fusarium toxin in dietary foods from high-risk areas of cancer of esophagus and gastric cardia in China, induced benign and malignant tumors in mice. Oncology Reports, 12, 449-456. 
JAJIĆ I.M., BOČAROV-STANČIĆ A.S., BIJELIĆ M.B. (2007): Investigations of the capability of Fusarium isolates from corn for byosynthesis of fusariotoxins. Proc. Nat. Sci., 113, 125-133.

JURIĆ V.B., JAJIĆ I.M., SAVKOVIĆ T.R., ABRAMOVIĆ B.F., RISTIĆ M.D., JURIĆ J.F. (2007): Wheat safety in relation to presence and content of deoxynivalenol. Proc. Nat. Sci., 113, 17-25.

KRNJAJA V.S., LEVIĆ J.T., NEŠIĆ Z.D., STANKOVIĆ S.Ž. (2009a): Effects of fertilisers on winter wheat infection caused by Fusarium species. Proc. Nat. Sci., 116, 61-66.

KRNJAJA V., LEVIĆ J., STANKOVIĆ S. (2008): Pathogenic fungi on wheat grain in Serbia. X International Fusarium and Fusarium Genomics Workshop 2008. Journal of Plant Pathology, 90, 3, Supplement, 84.

KRNJAJA V., LEVIĆ J., STANKOVIĆ S. (2009b): Ubiquity of toxigenic fungi and mycotoxins in animal feeds in Republic of Serbia. Biotechnology in Animal Husbandry, 25, 5-6, 477-491.

KRNJAJA V., LEVIĆ J., TOMIĆ Z., STANKOVIĆ S. (2006): The participation of potentially toxigenic Fusarium species in mycopupulations isolated from maize grain. Journal of Mountain Agriculture on the Balkans, 9, 4, 532-541.

KRNJAJA V., LEVIĆ J., TOMIĆ Z., NEŠIĆ Z., STOJANOVIĆ LJ., TRENKOVSKI S. (2007): Dynamics of incidence and frequency of populations of Fusarium species on stored maize grain. Biotehnology in Animal Husbandry, Book 1, 23, 5-6, 589-600.

LEATH K.T., KENDALL W.A. (1978): Fusarium root rot of forage species: pathogenicity and host range. Phytopathology, 68, 826-831.

LESLIE J.F. (1991): Mating populations in Gibberella fujikuroi (Fusarium section Liseola). Phytopathology, 81, 1058-1060.

LESLIE J.F. (1995): Gibberella fujikuroi: available populations and variable traits. Canadian Journal of Botany, 73, S282-S291.

LESLIE J.F., SUMMERELL A.B. (2006): The Fusarium laboratory manual. Blackeell Publishing, Ames, Iowa, USA, 388 p.

LEVIĆ J. (2008): Vrste roda Fusarium u oblasti poljoprivrede, veterinarske i humane medicine. Cicero, Beograd, $1226 \mathrm{p}$.

LEVIĆ J., STANKOVIĆ S., BOČAROV-STANČIĆ A., ŠKRINJAR M., MAŠIĆ Z. (2004): The overview on toxigenic fungi and mycotoxins in Serbia and Montenegro. In: LOGRIECO A., VISCONTI A. (eds), An overview on toxigenic fungi and mycotoxins in Europe. Kluwer Academic Publishers, Dordrecht, Boston, London, 201-218.

LEVIĆ J., STANKOVIĆ S., IVANOVIĆ D., KRNJAJA V., KOVAČEVIĆ T., TANČIĆ S., BOČAROV-STANČIĆ A. (2008a): Fusarium head blight and grain yield losses of wheat in Serbia. Cereal Research Communications, 36, Supplementum B, 513-514. 
LEVIĆ J., STANKOVIĆ S., KRNJAJA V. (2008b): Štetni mikroorganizmi u uskladištetnom žitu. In: KLJAJIĆ P. (ed.), Zaštita uskladištenih biljnih proizvoda od štetnih organizama. Vizartis, Beograd, 39-66.

LOGRIECO A., MULÉ G., MORETTI A., BOTTALICO A. (2002): Toxigenic Fusarium species and mycotoxins associated with maize ear rot in Europe. European Journal of Plant Pathology, 108, 597-609.

MARASAS W.F.O., NELSON P.E., TOUSSOUN T.A. (1984): Toxigenic Fusarium species: identity and mycotoxicology. Pennsylvania State University Press, University Park, PA.

MORETTI A., LOGRIECO A., VISCONTI A., BOTTALICO A. (2002): An overwiew of mycotoxins and toxigenic fungi in Italy. In: LOGRIECO A., VISCONTI A. (eds), An overview on toxigenic fungi and mycotoxins in Europe. Kluwer Academic Publishers, London.

NAKAJIMA T. (2007): Making evidence-based good agricultural practice for the reduction of mycotoxin contamination in cereals. FFTC Annual Report, 111-120.

NIRENBERG H.I., O'DONNELL K. (1998): New Fusarium species and combinations within the Gibberella fujikuroi species complex. Mycologia, 90, 434-458. NELSON P.E., TOUSSOUN T.A., MARASAS W.F.O. (1983): Fusarium species: an illustrated manual for identification. The Pennsylvania State University Press, University Park and London, $193 \mathrm{p}$.

O'DONNELL K., WARD T.J., GEISER D.M., KISTLER H.C., AOKI T. (2004): Genealogical concordance between the mating type locus and seven other nuclear genes supports formal recognition of nine phylogenetically distinct species within the Fusarium graminearum clade. Fungal Genetics and Biology, 41, 600-623.

PLACINTA C.M., D'MELLO J.P.F., MACDONALD A.M.C. (1999): A review of worldwide contamination of cereal grains and animal feed with Fusarium mycotoxins. Animal Feed Science and Technology, 78, 21-37.

PROTIĆ N.M., PROTIĆ R.J. (2005): Correlations of concentration of fumonisins and yield grain of wheat. Proc. Nat. Sci., 108, 129-137.

SLUŽBENI LIST SFRJ (1990): Pravilnik o maksimalnim količinama štetnih materija i sastojaka u stočnoj hrani. Br. 2.

STANKOVIĆ S., LEVIĆ J., KRNJAJA V., BOČAROV-STANČIĆ A., TANČIĆ S., KOVAČEVIĆ T. (2007): Frequency of toxigenic Fusarium species and fusariotoxins in wheat grain in Serbia. Proc. Nat. Sci., 113, 93-102.

STANKOVIĆ S., TANČIĆ S., LEVIĆ J., KRNJAJA V. (2008a): Production of deoxynivalenol by Fusarium graminearum and Fusarium culmorum isolated from wheat kernels in Serbia. Cereal Research Communications, 36, Supplementum B, 395-396.

STANKOVIĆ S., LEVIĆ J., PETROVIĆ T., KRNJAJA V. (2008b): Toxicological profile of $F$. proliferatum isolated from maize seed, root and stalk. Cereal Research Communications, 36, Supplementum B, 397-398. 
STOJANOVIĆ T.V., ŠKRINJAR M.M., PSODOROV Đ.B. (2005): Mycological and mycotoxicological quality of wheat and flour fractions. Proc. Nat. Sci., 108, 37-42. STACK J. (2000): Grain molds and mycotoxins in corn. University of Nebraska, Lincoln Extension, http://digitalcommons.unl.edu/extensionhist/89/

TANČIĆ S. (2009): Varijabilnost toksigenih vrsta roda Fusarium i fuzariotoksina u različitim agroekološkim uslovima uzgajanja kukuruza i pšenice. Doktorska disertacija, Univerzitet u Beogradu, $119 \mathrm{p}$.

TODOROV D., STOJŠIN V., PETROVIĆ R., MILIJIĆ S. (1995): Paraziti i štetočine krmnog bilja i njihovo suzbijanje. Drugo jugoslovensko savetovanje o zaštiti bilja. Vrnjačka Banja, 30. oktobar - 3. novembar 1995. Zbornik rezimea, 45-46. ŽIVKOVIĆ G.R., ŽIVANOV N.M., ŽIVKOVIĆ J.Z., MILOJEVIĆ M.J., TEODOSIN J.M., PEĆANAC S.L., MILIĆ D.V., BOČAROV-STANČIĆ A.S., ĐEKIĆ J.P. (2005): Mycotoxins and their impact on poultry production. Proc. Nat. Sci., 108, 197-205. 